\title{
Flow variability near the Cape Verde frontal zone (subtropical Atlantic Ocean)
}

\section{Variabilité des courants près de la zone frontale du Cap Vert (Atlantique subtropical)}

\author{
Annick Vangriesheim ${ }^{\mathrm{a}, *}$, Claudie Bournot-Marec $^{\mathrm{b}}$, Anne-Claire Fontan ${ }^{\mathrm{c}}$ \\ a Ifremer DRO/EP BP 70, 29280 Plouzané, France \\ ${ }^{b}$ INSU/CNRS Division Technique, BP 74, 29280 Plouzané, France \\ ${ }^{c}$ Météo-France, DIR de La Réunion, BP 4, 97491 Sainte-Clotilde cedex, France
}

Received 2 July 2002; revised and accepted 17 October 2002

\begin{abstract}
During the JGOFS-France/Eumeli programme, biogeochemical processes governing particle fluxes throughout the water column were studied in the Eastern Subtropical North Atlantic Ocean. From February 1991 to December 1992, three consecutive sets of sediment trap moorings were installed at two sites: the mesotrophic site: $\sim 18^{\circ} 30 \mathrm{~N}, 21^{\circ} 00 \mathrm{~W}$, and the oligotrophic site: $\sim 21^{\circ} 00 \mathrm{~N}, 31^{\circ} 00 \mathrm{~W}$. Currents were measured at each sediment trap level $(250,1000$ and $2500 \mathrm{~m})$ in order to understand better the dynamics in this area and its influence on the particle fluxes through the water column and to monitor the current speed conditions during the particle trapping. The results of these current measurements are presented here, including statistics, spectral analysis, horizontal and vertical correlations and the time variability which is studied by comparisons with previous studies and models. The main feature of the dynamics in this area is the presence of the Cape Verde frontal zone at the southeastern part of the North Atlantic subtropical gyre, which is an unstable boundary between the North Atlantic Central Water and the South Atlantic Central Water. At $250 \mathrm{~m}$, highest mean current speeds $\left(\sim 8-14 \mathrm{~cm} \mathrm{~s}^{-1}\right)$ and highest variability are encountered at the mesotrophic site which is the closest to this frontal zone, whereas they are $\sim 8 \mathrm{~cm} \mathrm{~s}^{-1}$ at the oligotrophic site. At 1000 and $2500 \mathrm{~m}$, they are of the same order for the two sites ( $\sim 5$ and $3 \mathrm{~cm} \mathrm{~s}^{-1}$, respectively). In addition to the short time scale variability at the inertial periods (33.4 and $38 \mathrm{~h}$ ) and semi-diurnal tidal period, long time scale variability at $\sim 100 \mathrm{~d}$ is very high at 250 and $1000 \mathrm{~m}$, particularly on the meridional component. Comparisons show that this result fits and expands previous eulerian and lagrangian observations and is consistent with Rossby waves predicted by models, in spite of small discrepancies.
\end{abstract}

(C) 2003 Éditions scientifiques et médicales Elsevier SAS and Ifremer/CNRS/IRD. All rights reserved.

\section{Résumé}

Au cours du programme JGOFS-France/Eumeli, les processus biogéochimiques associés aux flux de particules ont été étudiés dans l'océan Atlantique subtropical Est. De février 1991 à décembre 1992, trois séries consécutives de mouillages de pièges à particules ont été installées à deux sites : le site mésotrophe $\left(\sim 18^{\circ} 30 \mathrm{~N}, 21^{\circ} 00 \mathrm{~W}\right)$ et le site oligotrophe $\left(21^{\circ} 00 \mathrm{~N}, 31^{\circ} 00 \mathrm{~W}\right)$. Les courants ont été mesurés à chaque niveau de piège $(250,1000$ et $2500 \mathrm{~m})$ afin de mieux comprendre la dynamique de cette région et son influence sur les flux particulaires dans la colonne d'eau et de contrôler les conditions de vitesse du courant pendant la collecte des particules. Les résultats de ces mesures de courant présentés ici comprenent les statistiques, l'analyse spectrale, les corrélations horizontales et verticales et la variabilité temporelle qui est étudiée en référence aux études antérieures et aux modèles. La dynamique de cette région est dominée par la présence de la zone frontale du Cap Vert à la partie sud-est de la circulation anticyclonique subtropicale, qui est une limite instable entre l'Eau Centrale Nord Atlantique et l'Eau Centrale Sud Atlantique. A $250 \mathrm{~m}$, c'est au site mésotrophe proche de cette zone frontale que les vitesses moyennes de courant sont les plus élevées $\left(\sim 8-14 \mathrm{~cm} \mathrm{~s}^{-1}\right)$ et les plus variables alors qu'elles sont $\sim 8 \mathrm{~cm} \mathrm{~s}^{-1}$ au site oligotrophe. À 1000 et $2500 \mathrm{~m}$, elles sont du même ordre de grandeur aux deux sites ( $\sim 5$ et $3 \mathrm{~cm} \mathrm{~s}^{-1}$, respectivement). En plus de la variabilité aux périodes d'inertie (33,4 et 38 heures) et semi-diurne,

\footnotetext{
* Corresponding author.

E-mail address: annick.vangriesheim@ifremer.fr (A. Vangriesheim).
} 
la variabilité à plus longue période ( 100 jours) est forte à 250 et 1000 m, particulièrement sur la composante méridienne du courant. Des comparaisons montrent que ces résultats confirment et complètent de précédentes observations eulériennes et lagrangiennes et sont cohérentes avec les modèles d'ondes de Rossby, malgré de petites disparités.

(C) 2003 Éditions scientifiques et médicales Elsevier SAS and Ifremer/CNRS/IRD. Tous droits réservés..

Keywords: North Atlantic Ocean; Eastern subtropical; Cape Verde frontal zone; Current, variability; Rossby waves

Mots clés : Océan Atlantique Nord ; Subtropical Est ; Cap Vert ; Courant, variabilité ; Ondes de Rossby

\section{Introduction}

The JGOFS-France/Eumeli programme took place in 1989 and 1991-1992 in the Northeast Atlantic subtropical area off the African coast Fig. 1). It aimed to study the progressive changes in the biogeochemical processes and fluxes due to the Mauritanian upwelling dissipation in three different areas characterised by decreasing trophic conditions (from rich to poor surface primary production), the so-called eutrophic, mesotrophic and oligotrophic sites located at $\sim 20^{\circ} 32 \mathrm{~N}, 18^{\circ} 36 \mathrm{~W}, \sim 18^{\circ} 30 \mathrm{~N}, 21^{\circ} 00 \mathrm{~W}$ and $\sim 21^{\circ}$ $00 \mathrm{~N}, 31^{\circ} 00 \mathrm{~W}$, respectively (Morel, 1996).

The ocean dynamics in this region are mainly characterised by the upwelling regime near the African coast and by the westward-flowing North Equatorial Current (NEC), which is the southern boundary of the North Atlantic sub- tropical gyre. This region is also a frontal zone between the North Atlantic Central Water (NACW) and the South Atlantic Central Water (SACW): the Central Water Boundary (CWB). This frontal zone, called the Cape Verde frontal zone (CVFZ) by Zenk et al. (1991), is unstable and generates mesoscale variability in this area as modelled by Onken and Klein (1991), Spall (1992) and observed by Zenk et al. (1991), Müller and Siedler (1992), Spall et al. (1993). The model from Onken and Klein (1991) predicts the periods and wavelengths expected at different water depths in this CVFZ. In this model, growth and eddy generation are caused by baroclinic instability confirmed by Erasmi et al. (1998). The resulting temporal variability is dominated by baroclinically unstable waves and eddies propagating westward in the upper layers $(0-200 \mathrm{~m})$. In the intermediate layers, most of the energy is contained in the $100-125 \mathrm{~d}$ range. In the deep layers

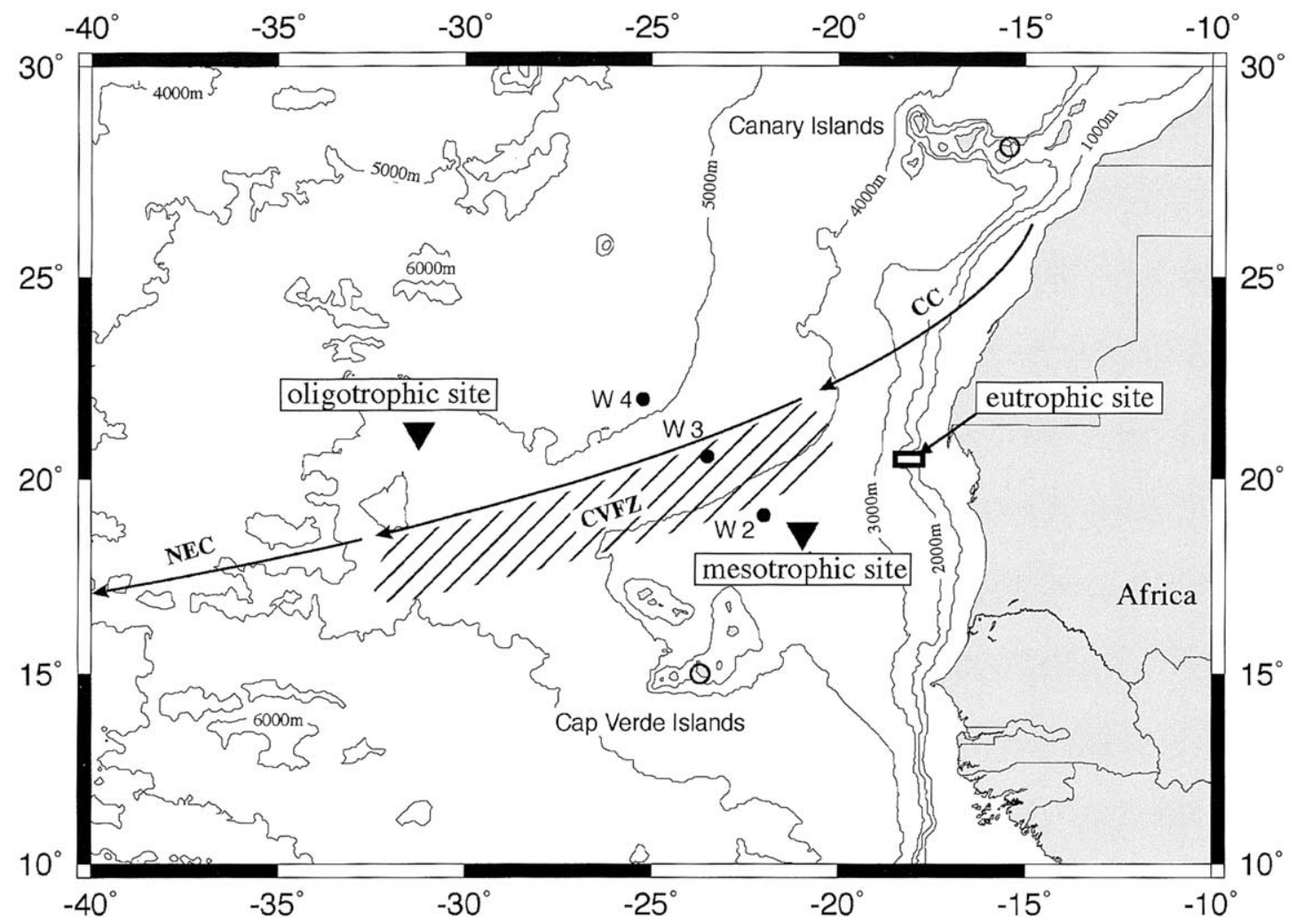

Fig. 1. Locations of the oligotrophic, mesotrophic and eutrophic sites studied during the Eumeli programme. Arrows indicate all year round current features: CC is the Canary Current; NEC is the North Equatorial Current. CVFZ is the Cap Verde Frontal Zone (dashed area). The moorings of sediment traps and current meters of the Eumeli programme were installed at the oligotrophic and mesotrophic sites ( $\mathbf{\nabla})$. W2, W3 and W4 ( ) are the locations of moorings previously installed by IFM (Müller and Siedler, 1992). 
(1000 $\mathrm{m}$ to the bottom), there are fast moving Rossby waves travelling westward with short periods $(<50 \mathrm{~d})$, and longer period topographic Rossby waves travelling slowly eastward. Moreover, Spall (1992) and Spall et al. (1993) emphasised the fact that environmental conditions are favourable for a radiation of these Rossby waves away from the CVFZ. The mesoscale variability is in favour of the mixing of the water masses encountered in this frontal zone which has important consequences on the downward fluxes in the water column. Dadou et al. (1996) studied the effects of the timedependent mesoscale meandering of the NEC on the pelagic ecosystem by means of a biological/physical coupled model applied to the Eumeli area. The Eumeli programme provided field data to study these phenomena.

During the Eumeli programme, five cruises were organised between 1989 and 1992. Those of 1991-1992 (Eumeli 2 to Eumeli 5) performed intensive observations and sampling in the euphotic layer, the water column and the benthic compartment (Morel, 1996). Hydrographic surveys performed during the Eumeli 2 cruise (February 1991) allowed a water mass analysis showing the Central Water competition as well as the other water mass characteristics (Vangriesheim et al., 1993; Pierre et al., 1994). They made it possible to observe that the Central Water found at $250 \mathrm{~m}$ at site $\mathrm{O}$ was the NACW only, while there is an alternation of the warmer NACW and of the cooler SACW at site M (Pierre et al., 1994). This indicates that, in February 1991, the CVFZ might have been near site M. At $1000 \mathrm{~m}$ is the level of the Antarctic Intermediate Water (AAIW) characterised by a salinity minimum at site $\mathrm{O}$ and the upper level of the North Atlantic Deep Water at site M. At $2500 \mathrm{~m}$ is the NADW (Vangriesheim et al., 1993).

In between the four cruises of 1991-1992, three sets of long term moorings of sediment traps (250, 1000 and $2500 \mathrm{~m}$ ) were deployed at the mesotrophic site and at the oligotrophic site (site $\mathrm{M}$ and site $\mathrm{O}$ in the following) in order to measure the particle flux time-variations in the water column. Other long term sediment trap moorings were also installed in 1991-1992 in the near-bottom layer (Khripounoff et al., 1998). In order to study the water column dynamics, its variability and its effect on the advective transport and to take account of the current speed effects on the particle trapping, current meters were installed near each sediment trap for all the deployments. The interactions between the current and the suspended particle behaviour in the water column have been discussed in Tachikawa et al. (1999), the interactions with the settling particles are analysed in Bory et al. (2001) for the upper and deep water column and in Khripounoff et al. (1998) for the near-bottom water column. The purpose of this paper is to present and analyse the current data set at 250, 1000 and $2500 \mathrm{~m}$ (statistics, time variability, spectral analysis, horizontal and vertical correlations) and to detail the low frequency oscillation propagation on a distance larger than the previous field studies with reference to modelling studies in this area.

\section{Data set}

The moorings deployed three times between February 1991 and December 1992 at the two sites were composed of three sets of sediment traps/Aanderaa current meters, the current meter being $10 \mathrm{~m}$ below the trap in order to prevent particle flux perturbations. The current meters placed at 250, 1000 and $2500 \mathrm{~m}$ were either RCM5, RCM7 or RCM8 depending on the depth. They recorded current speed and direction, temperature and pressure at a time interval of $1 \mathrm{~h}$. Pressure and temperature sensors as well as rotors had been calibrated at the Calibration Laboratory of Ifremer-Brest (France). Taking into account these calibrations and the data digitisation, the resolution and accuracy of the data are 0.024 and $0.05{ }^{\circ} \mathrm{C}$ for temperature, 2.5 and $20 \mathrm{~mm} \mathrm{~s}^{-1}$ for current speed, $0.35^{\circ}$ and $7.5^{\circ}$ for current direction, respectively. Mooring locations and dates are summarised in Table 1

The data return was very good for the first period (Eumeli 2 to Eumeli 3) but lesser for the two other periods where the shallower records were sometimes shortened. Fig. 2 shows the time duration of each record. The total record duration varies from 405 to $665 \mathrm{~d}$ depending on the level. Gap durations are also indicated. The current meter installed at $2500 \mathrm{~m}$ at site $\mathrm{M}$ between Eumeli 2 and Eumeli 3 recorded bad current directions when the speed was low; hence only speed and temperature measurements are correct in this timeseries. No current meter was installed at $250 \mathrm{~m}$ at site $\mathrm{O}$ between Eumeli 3 and Eumeli 4. Detailed plots of these data are in a data report (Bournot et al., 1995) where all the details about the moorings and the data processing are also given.

To remove the high frequency fluctuations that hide the lower ones, a low-pass filter (Lanczos filter with a cut-off period of $4 \mathrm{~d}$ ) was applied on the East and North components ( $\mathrm{U}$ and $\mathrm{V}$ ) and temperature time-series. Then, in the filtered time-series, data were interpolated in the small gaps $(\leq 6 \mathrm{~d}$ only, Fig. 2.

Table 1

Dates and locations of the three mooring deployments at site $\mathrm{O}$ and site $\mathrm{M}$ during the Eumeli programme

\begin{tabular}{llll}
\hline & Eumeli 2 to Eumeli 3 & Eumeli 3 to Eumeli 4 & Eumeli 4 to Eumeli 5 \\
\hline Site O & 17 February 1991 to 21 September 1991 & 24 September 1991 to 24 May 1992 & 27 May 1992 to 22 December 1992 \\
& $21^{\circ} 03.986 \mathrm{~N}, 031^{\circ} 09.211 \mathrm{~W}$ & $21^{\circ} 03.26 \mathrm{~N}, 031^{\circ} 10.23 \mathrm{~W}$ & $21^{\circ} 0.94 \mathrm{~N}, 031^{\circ} 09.21 \mathrm{~W}$ \\
\multirow{2}{*}{ Site M } & Water depth: $4560 \mathrm{~m}$ & Water depth: $4550 \mathrm{~m}$ & Water depth: $4512 \mathrm{~m}$ \\
& 11 February 1991 to 16 September 1991 & 18 September 1991 to 31 May 1992 & 03 June 1992 to 16 December 1992 \\
& $18^{\circ} 30.68 \mathrm{~N}, 021^{\circ} 05.56 \mathrm{~W}$ & $18^{\circ} 29.56 \mathrm{~N}, 021^{\circ} 05.82 \mathrm{~W}$ & $18^{\circ} 29.55 \mathrm{~N}, 021^{\circ} 05.47 \mathrm{~W}$ \\
& Water depth: $3100 \mathrm{~m}$ & Water depth: $3088 \mathrm{~m}$ & Water depth: $3090 \mathrm{~m}$ \\
\hline
\end{tabular}




\begin{tabular}{|c|c|c|c|c|c|}
\hline & & Eumeli 2-3 & Eumeli 3-4 & Eumeli 4-5 & Total \\
\hline \multirow{3}{*}{ MESO } & $250 \mathrm{~m}$ & 216 & 96 & & 405 \\
\hline & $1000 \mathrm{~m}$ & 216 & 199 & 196 & 611 \\
\hline & $2500 \mathrm{~m}$ & 216 & 253 & 196 & 665 \\
\hline \multirow{3}{*}{ OLIGO } & $250 \mathrm{~m}$ & 215 & 249 & 193 & 408 \\
\hline & $1000 \mathrm{~m}$ & 215 & 241 & 208 & 664 \\
\hline & $2500 \mathrm{~m}$ & 215 & 241 & 208 & 664 \\
\hline
\end{tabular}

Fig. 2. Time duration (in days) of each current meter time-series. The number in italics between each data set is the duration (in days) of the gap between the recovery and the launching of the moorings or the gap due to bad records. The current meter installed at $2500 \mathrm{~m}$ at site $\mathrm{M}$ between Eumeli 2 and Eumeli 3 recorded bad current directions when the speed was low; hence only speed and temperature are correct in this time-series. No current meter was installed at $250 \mathrm{~m}$ at site $\mathrm{O}$ between Eumeli 3 and Eumeli 4. The detailed dates of each time-series are given in the data report (Bournot et al., 1995).

\section{Results}

\subsection{Statistics}

The general statistics for the current speed, the $\mathrm{U}$ and $\mathrm{V}$ components and the temperature of each data set are in Fig. 3

In Fig. 3a it appears that the mean speed (scalar mean) is higher at $250 \mathrm{~m}$ at site $\mathrm{M}\left(\sim 8-14 \mathrm{~cm} \mathrm{~s}^{-1}\right)$ than at site $\mathrm{O}$ $\left(\sim 8 \mathrm{~cm} \mathrm{~s}^{-1}\right)$. This difference does not appear at the other two levels where they are of the same order $\left(\sim 5 \mathrm{~cm} \mathrm{~s}^{-1}\right.$ at $1000 \mathrm{~m}$ and $\sim 3 \mathrm{~cm} \mathrm{~s}^{-1}$ at $2500 \mathrm{~m}$ ). The standard deviation too is much higher at $250 \mathrm{~m}$ at site $\mathrm{M}$, which is consistent with higher maximum speeds. Some differences are noticeable over time. Mean speeds and standard deviations appear to be smaller between Eumeli 3 and Eumeli 4, i.e. between September 1991 and June 1992.

In Fig. 3b it can be seen that the two mean components are quite often negative which gives a mean current to the SW sector consistent with the long term circulation of the NEC (values of $U$ and $V$ in Table 2p. Again, the values and the standard deviations are much higher at site $\mathrm{M}$ than at site $\mathrm{O}$ for $250 \mathrm{~m}$.

In Fig. 3c which concerns the mean temperatures, the shallowest level is warmer at site $\mathrm{O}\left(15-20^{\circ} \mathrm{C}\right)$ than at site $\mathrm{M}$ $\left(12-13{ }^{\circ} \mathrm{C}\right.$ ) which is consistent with the water mass analysis (Pierre et al., 1994). Actually, this level is the upper limit of

Table 2

Mean east and west components of the currents $(\bar{U}$ and $\bar{V})$ at the two sites $O$ and $\mathrm{M}$ during the Eumeli programme

\begin{tabular}{lcll}
\hline & Depth $(\mathrm{m})$ & $\bar{U}\left(\mathrm{~cm} \mathrm{~s}^{-1}\right)$ & $\bar{V}\left(\mathrm{~cm} \mathrm{~s}^{-1}\right)$ \\
\hline Site $\mathrm{O}$ & 250 & -2.32 & -2.67 \\
& 1000 & -0.80 & -0.02 \\
\multirow{4}{*}{ Site $\mathrm{M}$} & 2500 & -0.61 & 0.52 \\
& 250 & -4.69 & -0.96 \\
& 1000 & -0.90 & -0.42 \\
& 2500 & 0.18 & -0.54 \\
\hline
\end{tabular}

the Central Water, which is the warmer NACW at site $\mathrm{O}$ while it is a mixing of the NACW and the colder SACW at site M (Pierre et al., 1994). In addition to this true difference, some other differences appear on this figure at each level from a cruise to another (except at $2500 \mathrm{~m}$ where the temperature gradient is very small). They are due to changes in the exact immersion of the currentmeter from a mooring line to another one.

Spectral analysis performed on the current meter data shows that the high frequency variability is very high at each level and each site. In Fig. 4 two very high peaks appear at each site and each level corresponding to inertial oscillations and to semi-diurnal tidal oscillations. The theoretical inertial period is $33.4 \mathrm{~h}$ (latitude: $\sim 21^{\circ} 04 \mathrm{~N}$ ) at site $\mathrm{O}$ and $38 \mathrm{~h}$ (latitude: $\sim 18^{\circ} 30 \mathrm{~N}$ ) at site $\mathrm{M}$. The inertial peak is large, whereas the semi-diurnal peak is very sharp. From spectral analysis, the semi-diurnal tide ellipses are mainly oriented north-south at both sites, which is consistent with the results of Siedler and Paul (1991). Diurnal and quarter-diurnal oscillations have also a small contribution. Comparisons between the two sites show that at $250 \mathrm{~m}$ energy is higher at site $\mathrm{M}$ than at site $\mathrm{O}$ for all periods. At the other two levels, only the mean and long periods (> 200 h) have higher energy at site $\mathrm{M}$ than at site $\mathrm{O}$.

\subsection{Time variability}

To examine the mesoscale fluctuations, the data were low-pass filtered in such a way that all the fluctuations with a period shorter than $4 \mathrm{~d}$ are removed (Lanczos filter, cut-off period: 4 d). Fig. 5 represents values of the mean kinetic energy $K_{\mathrm{M}}\left(K_{\mathrm{M}}=1 / 2\left(\bar{U}^{2}+\bar{V}^{2}\right)\right)$ and the eddy kinetic energy $K_{\mathrm{E}}\left(K_{\mathrm{E}}=\frac{1}{2}[\operatorname{var}(U)+\operatorname{var}(V)]\right)$ before and after filtering.

$K_{\mathrm{M}}$ is the energy of the mean current and $K_{\mathrm{E}}$ is an indication of the energy of the speed and direction fluctuations around the mean. Though $K_{\mathrm{E}}$ is highly reduced by filtering at all levels, it is obvious that it is still higher at site $\mathrm{M}$ than at site $\mathrm{O}$, showing that the eddy energy difference between both sites is due to the low frequency oscillations. The eddy kinetic energy $K_{\mathrm{E}}$ calculated on the filtered data series joined end to end are 61,6 and $1 \mathrm{~cm}^{2} \mathrm{~s}^{-2}$ at site $\mathrm{M}$ (at 250,1000 and $2500 \mathrm{~m}$, respectively) and 19,4 and $1 \mathrm{~cm}^{2} \mathrm{~s}^{-2}$ at site $\mathrm{O}$ (at 250, 1000 and $2500 \mathrm{~m}$, respectively). The previous long time-series obtained by IFM (Institut für Meereskunde, University of Kiel, Germany) in the Canary basin (Müller and Siedler, 1992) allow some comparisons: they provided $K_{\mathrm{E}}$ values of $30 \mathrm{~cm}^{2} \mathrm{~s}^{-2}$ at $200 \mathrm{~m}$ between site $\mathrm{O}$ and site $\mathrm{M}$ (at their W3 and W4 moorings, see locations in Fig. 1; they provided 6 and $8 \mathrm{~cm}^{2} \mathrm{~s}^{-2}$ around $1300 \mathrm{~m}$ (at W3 and W2) and 1.2 and $1.7 \mathrm{~cm}^{2} \mathrm{~s}^{-2}$ in the very deep (4500 and $5000 \mathrm{~m}$ at W3 and W4). These values are of the same order of those found from our data.

The filtered current is represented Fig. 6 as vectors to show the low frequency time-variations. A well-marked north-south oscillation is obvious from this figure. In order 

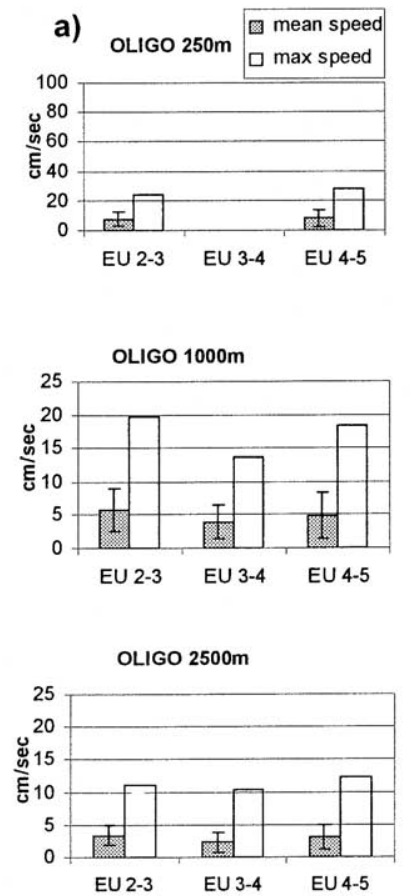
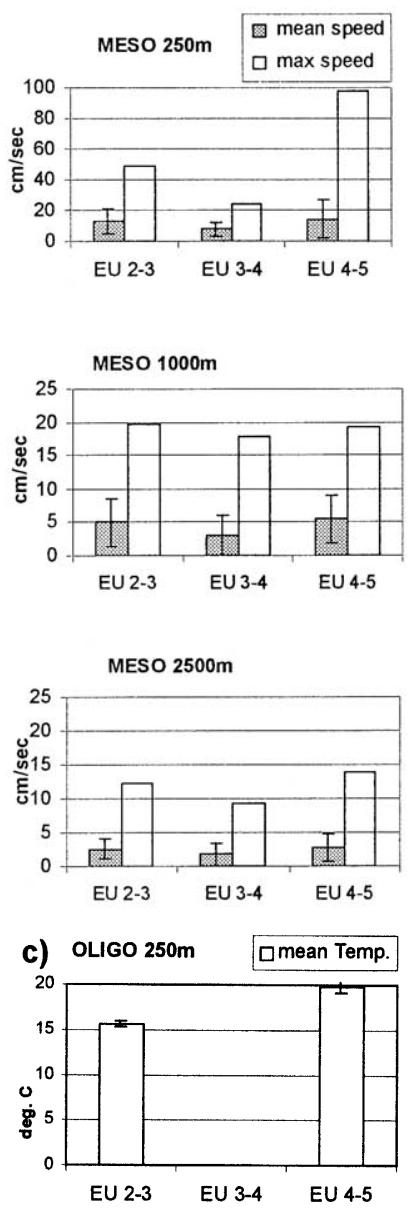

OLIGO $1000 \mathrm{~m}$
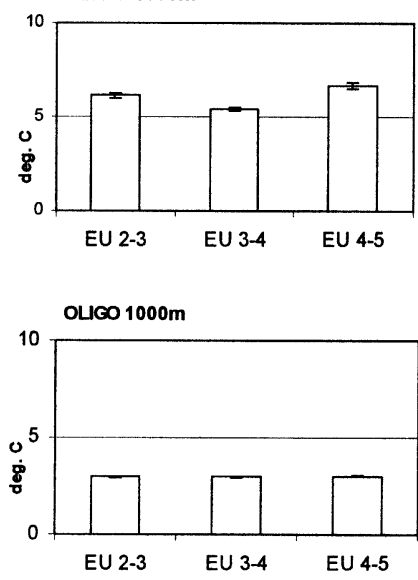
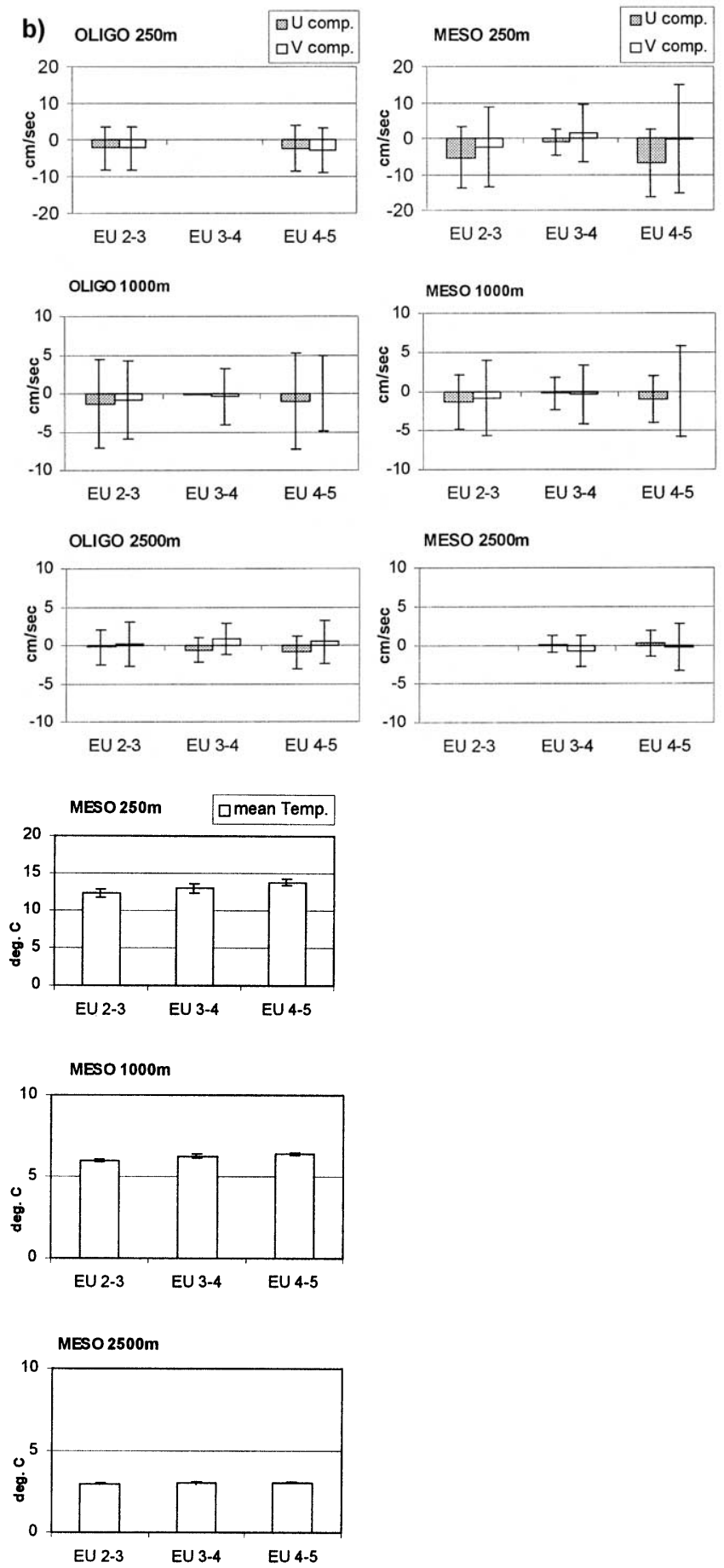

Fig. 3. Statistics for current and temperature at site $\mathrm{O}$ and site $\mathrm{M}$ at 250, 1000 and $2500 \mathrm{~m}$ for each (unfiltered) time-series: (a) mean speed (scalar mean) with standard deviation and maximum speed in $\mathrm{cm} \mathrm{s}^{-1}$; (b) mean east and west components ( $\bar{V}$ and $\bar{U}$ ) with standard deviation in $\mathrm{cm} \mathrm{s}^{-1}$ and (c) mean temperature with standard deviations in degrees $\mathrm{C}$.

to have a better idea of the residual direction of these oscillations, progressive vector diagrams have been plotted in Fig. 7 (note that these are fictitious trajectories and that there are data gaps in some of them). The mean component values $U$ and $V$ were already given in Table 2. No steady direction appears at $250 \mathrm{~m}$ except a residual westward flow, also noted at $1000 \mathrm{~m}$. At $1000 \mathrm{~m}$, some oscillations appear at both sites after the rapid south-westerly flow, ending around May 1991 at site M and late July 1991 at site O. During these oscillations, the current oscillates roughly from south-southwest to north-northeast at site $\mathrm{M}$ and from southeast to northwest at site $\mathrm{O}$. 


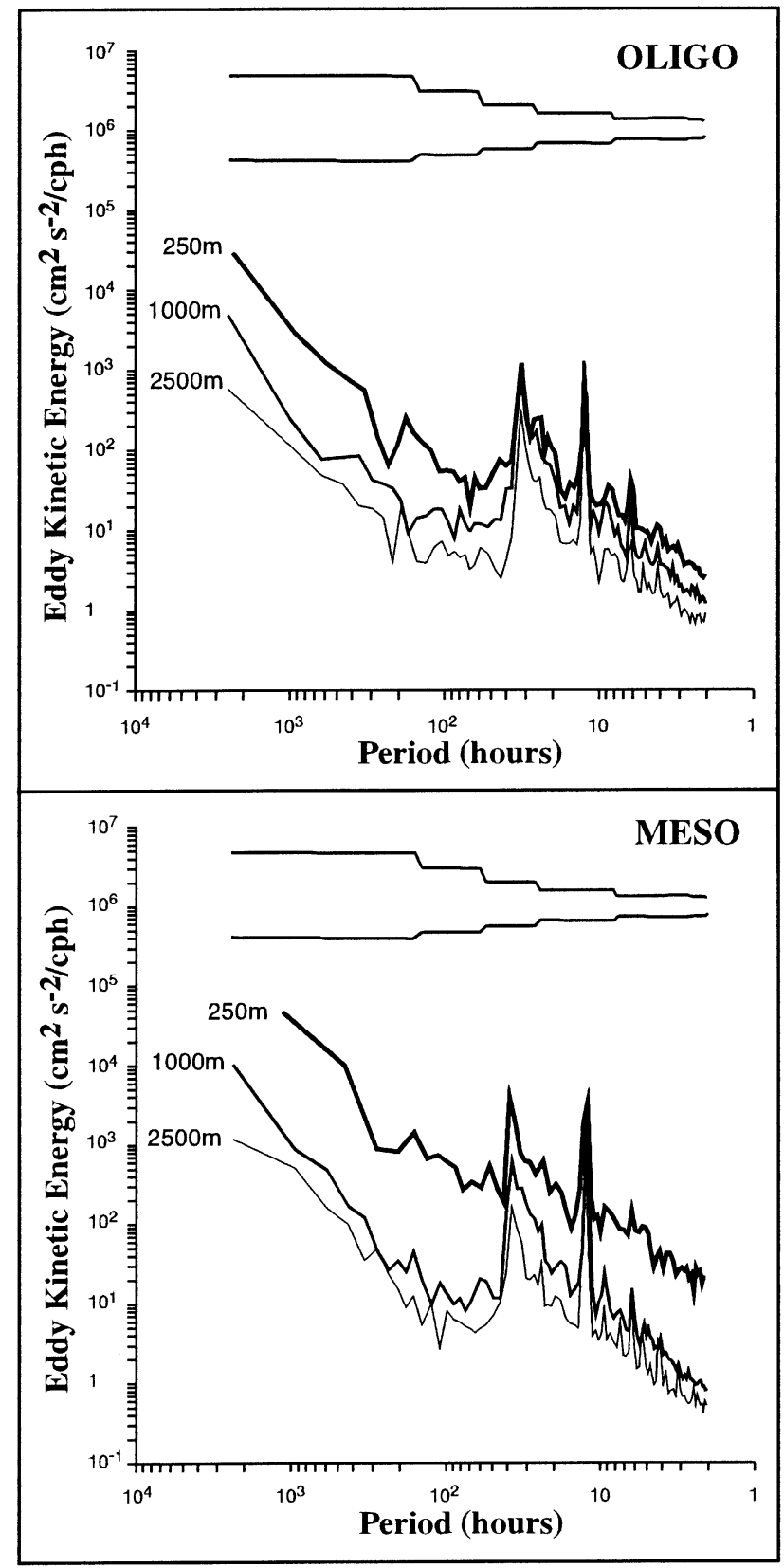

Fig. 4. Total kinetic energy spectrum (with confidence interval at $95 \%$ depending on the number of frequency bands taken for averaging) of the current meter unfiltered data sets obtained from Eumeli 4 to Eumeli 5. Top: site $\mathrm{O}(250,1000$ and $2500 \mathrm{~m})$; bottom: site $\mathrm{M}(250,1000$ and $2500 \mathrm{~m})$.

\subsection{Time scales}

The zonal and meridional autocorrelation functions were computed at each level for both sites. The integral time is calculated as the integral of this function from the time lag 0 until the time of the first zero crossing Table 3. It is a measure of the time for which the fluid remembers its previous state. At site $\mathrm{M}$, integral times for the $\mathrm{U}$ component are higher at $1000 \mathrm{~m}(11-22 \mathrm{~d})$ than at $250 \mathrm{~m} \mathrm{(5-19} \mathrm{d)} \mathrm{and} \mathrm{at}$ $2500 \mathrm{~m} \mathrm{(7} \mathrm{and} 8 \mathrm{~d})$. The scale of the zonal variability is thus longer at $1000 \mathrm{~m}$ than at 250 and $2500 \mathrm{~m}$. The integral times
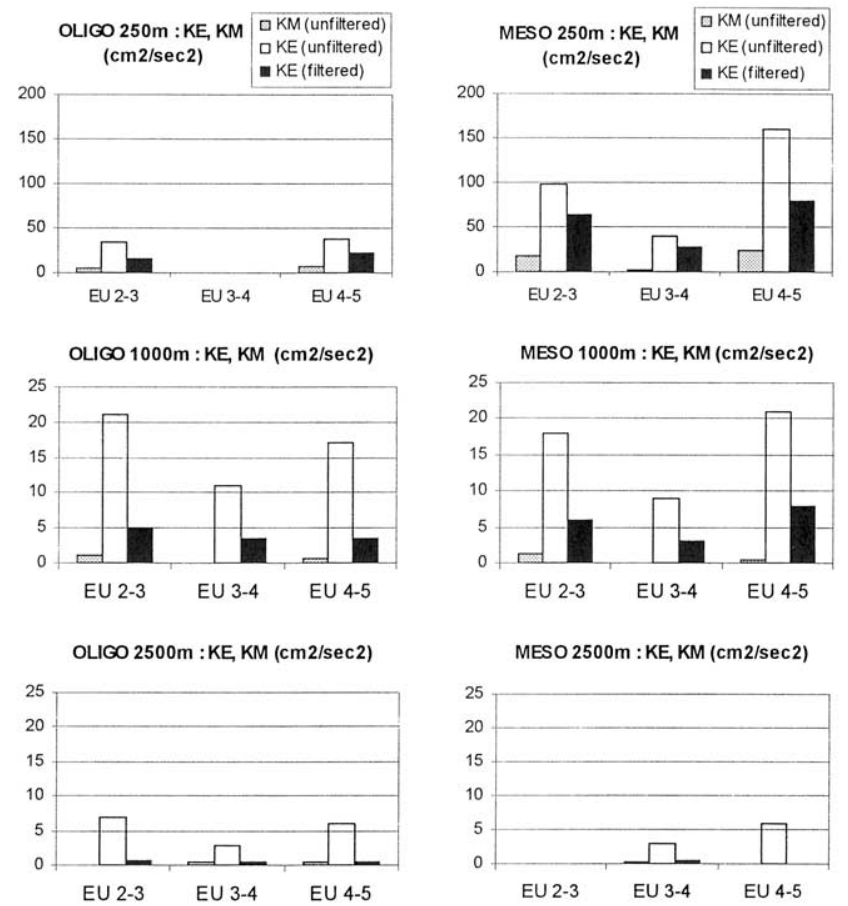

Fig. 5. Values of mean kinetic energy $K_{\mathrm{M}}$ and eddy kinetic energy $K_{\mathrm{E}}$ (before and after low-pass filtering) calculated at site $\mathrm{O}$ and site $\mathrm{M}$ at 250,1000 and $2500 \mathrm{~m}$ and for each time-series.

for the $\mathrm{V}$ component are more stable along the time and on the vertical (from 12 to $16 \mathrm{~d}$ ). At site $\mathrm{O}$, the integral time is also higher at $1000 \mathrm{~m}$ than at the other levels for the $\mathrm{U}$ component. The integral times for the $\mathrm{V}$ component are shorter than those for the U component (except at $2500 \mathrm{~m}$ ), which reflects that the variability is mainly in the meridional direction while the zonal direction is that of the mean current. Similar to at site M, the time scales are shorter at $2500 \mathrm{~m}$. That this time scale decreases towards the bottom is also supported by the near-bottom measurements (time scales less than $10 \mathrm{~d}$ at site $\mathrm{M}$ and site $\mathrm{O}$ ) simultaneously performed during the Eumeli programme (Khripounoff et al., 1998). The IFM long term data series (Müller and Siedler, 1992, Table 5a) also seem to have longer time scales at the intermediate levels $(\sim 1300 \mathrm{~m})$ and for the $\mathrm{U}$ component. The Lagrangian integral time calculated after Sofar float trajectories (obtained in a Northernward area) also gave higher time scales on the zonal component (Spall et al., 1993).

\subsection{Spectral distribution of energy}

Spectral analysis was also performed on the filtered data in order to examine the longer time periods Fig. 8). Unfortunately, the length and the data gaps in some time-series preclude this analysis from a very good statistical reliability for the long periods, particularly for the $250 \mathrm{~m}$ data series at site $\mathrm{O}$ where the gap is the biggest ( $249 \mathrm{~d}$ in the middle). Thus, the calculation was made, for each level, on the longest available time-series even if they are rather short. Nevertheless, one can notice higher energies in the period interval of 


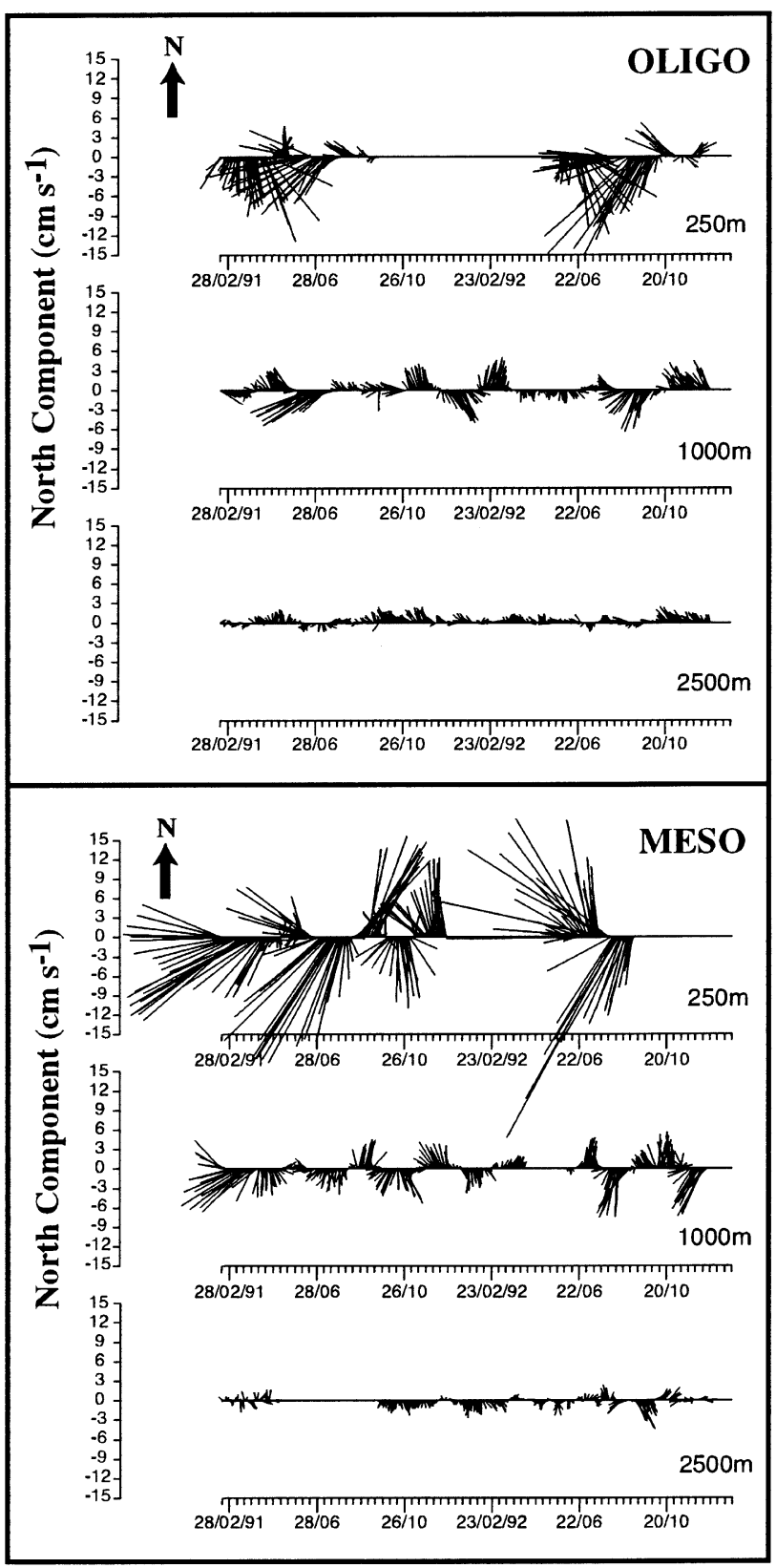

Fig. 6. Vector plots at site $\mathrm{O}$ (top) and site $\mathrm{M}$ (bottom) at 250, 1000 and $2500 \mathrm{~m}$ for the whole measurement duration from the low-pass filtered data-series (cut-off period of $4 \mathrm{~d}$ ) joined end to end (one vector every $2 \mathrm{~d}$ ).

2000-3000 h (i.e. $80-125$ d) at $1000 \mathrm{~m}$ for both sites. This period interval is the same as previously deduced from long term moorings (Müller and Siedler, 1992) and from Sofar float trajectories (Spall et al., 1993) and predicted by models (Onken and Klein, 1991; Spall, 1992). At 2500 m, at site M, a peak appears also at these periods.

\subsection{Horizontal correlations}

It can be seen from the vector plots Fig. 6 and from the progressive vector diagrams Fig. 7 that the long term oscillations observed at $1000 \mathrm{~m}$ at the two sites seem to be out of
Table 3

Integral time scales (days) calculated for low-pass filtered $\mathrm{U}$ and $\mathrm{V}$ components (at the first zero crossing of the autocorrelation function) for the three periods of mooring at site $\mathrm{O}$ and site $\mathrm{M}$ during the Eumeli programme

\begin{tabular}{llll}
\hline Site M & EU2-EU3 & EU3-EU4 & EU4-EU5 \\
\hline $250 \mathrm{~m}$ & & & \\
$U$ & 19 & 6 & 5 \\
$V$ & 14 & 15 & 12 \\
$1000 \mathrm{~m}$ & & 11 & 12 \\
$U$ & 22 & 16 & 14 \\
$V$ & 14 & & \\
$2500 \mathrm{~m}$ & & 8 & 7 \\
$U$ & & 13 & 10 \\
$V$ & & & \\
& & & EU3-EU4 \\
\hline Site O & EU2-EU3 & & 17 \\
\hline $250 \mathrm{~m}$ & & & 13 \\
$U$ & 20 & & 20 \\
$V$ & 14 & 25 & 19 \\
$1000 \mathrm{~m}$ & & 16 & 10 \\
$U$ & 19 & 4 & 14 \\
$V$ & 17 & No zero crossing & \\
$2500 \mathrm{~m}$ & & & \\
$U$ & 9 & & \\
$V$ & 12 & &
\end{tabular}

phase. Attempts to evaluate a phase lag from coherence calculation gave no significant results (due to the too short time-series). However, the correlation functions between the time-series Fig. 9 show the period of the oscillation and the time lag between the two sites. This correlation function is more indicative between the $\mathrm{V}$ components which are predominant in the oscillations than between the $\mathrm{U}$ components. From the correlation function between the $\mathrm{V}$ components at site $\mathrm{M}$ and site $\mathrm{O}$, the period can be estimated to be $\sim 100 \mathrm{~d}$ with a time lag of $80 \mathrm{~d}$. Conversely, the calculation of the correlation between site $\mathrm{O}$ and site $\mathrm{M}$ (not shown) gives a time lag of $26 \mathrm{~d}$ which is consistent with the period of $\sim 100 \mathrm{~d}$. This calculation indicates neither the direction of propagation nor the number of oscillations between the two sites. The westward propagation direction is deduced from the vector plots Fig. 6), where the strong events may be seen earlier at site $\mathrm{M}$ than at site $\mathrm{O}$ (especially at $1000 \mathrm{~m}$ ).

\subsection{Vertical correlations}

Choosing the longest pairs of time-series, vertical correlation functions were computed between 250 and $1000 \mathrm{~m}$ at both sites Fig. 10.

At site $\mathrm{M}$, the correlations are maximum for time lag 0 , meaning that the oscillations are in phase at these two levels (i.e. the barotropic signals are dominant). The oscillatory pattern appears mainly on the $\mathrm{V}-\mathrm{V}$ correlation with a period of $\sim 100 \mathrm{~d}$ (second positive correlation maximum at $\sim 100 \mathrm{~d}$ after a negative correlation maximum at half-period).

At site $\mathrm{O}$, the $\mathrm{U}-\mathrm{U}$ correlation function is maximum for a time lag of $14 \mathrm{~d}$. The $\mathrm{V}-\mathrm{V}$ correlation function decreases from time lag 0 but the lag between the $\mathrm{U}-\mathrm{U}$ and the $\mathrm{V}-\mathrm{V}$ 

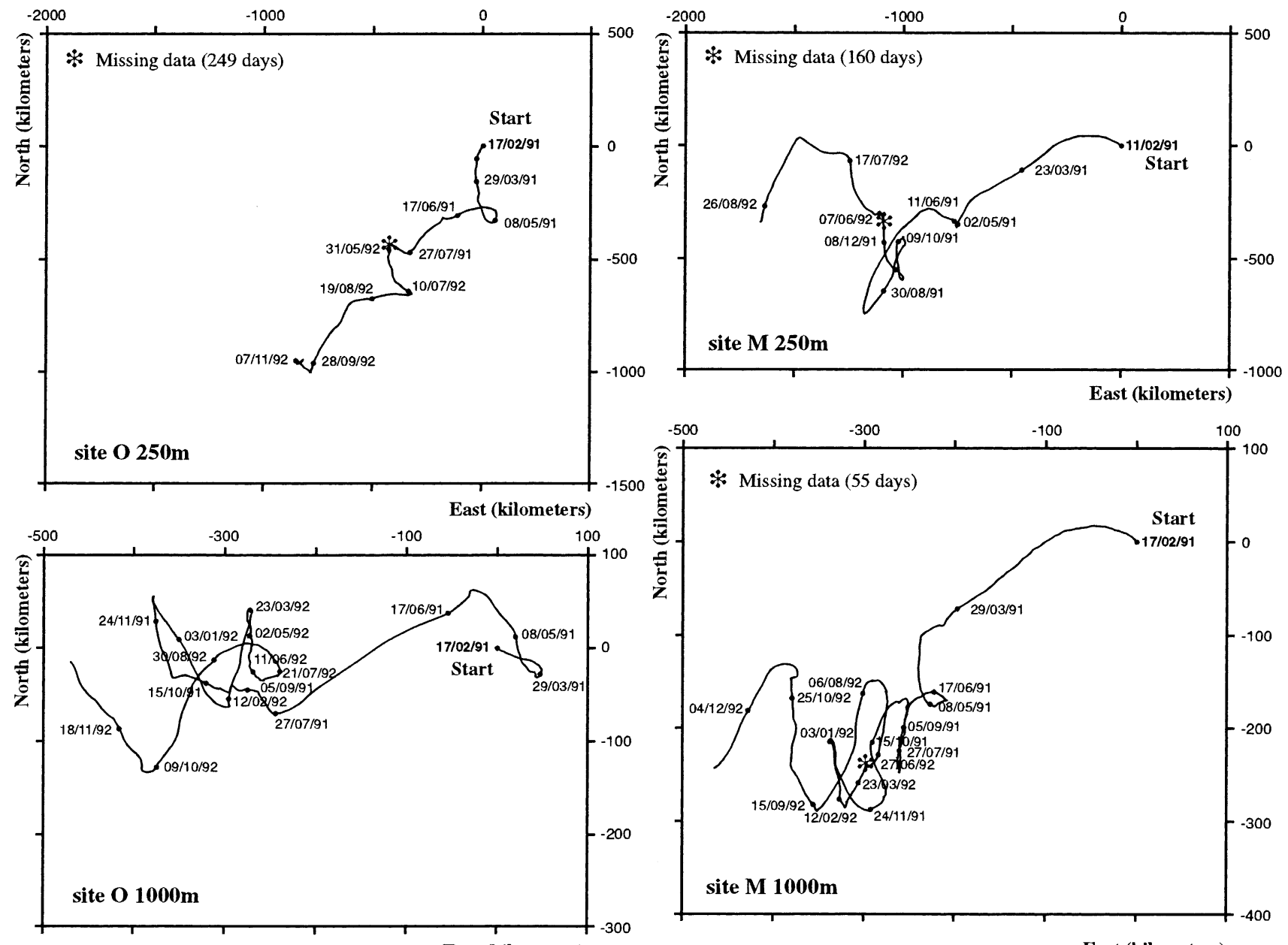

East (kilometers)
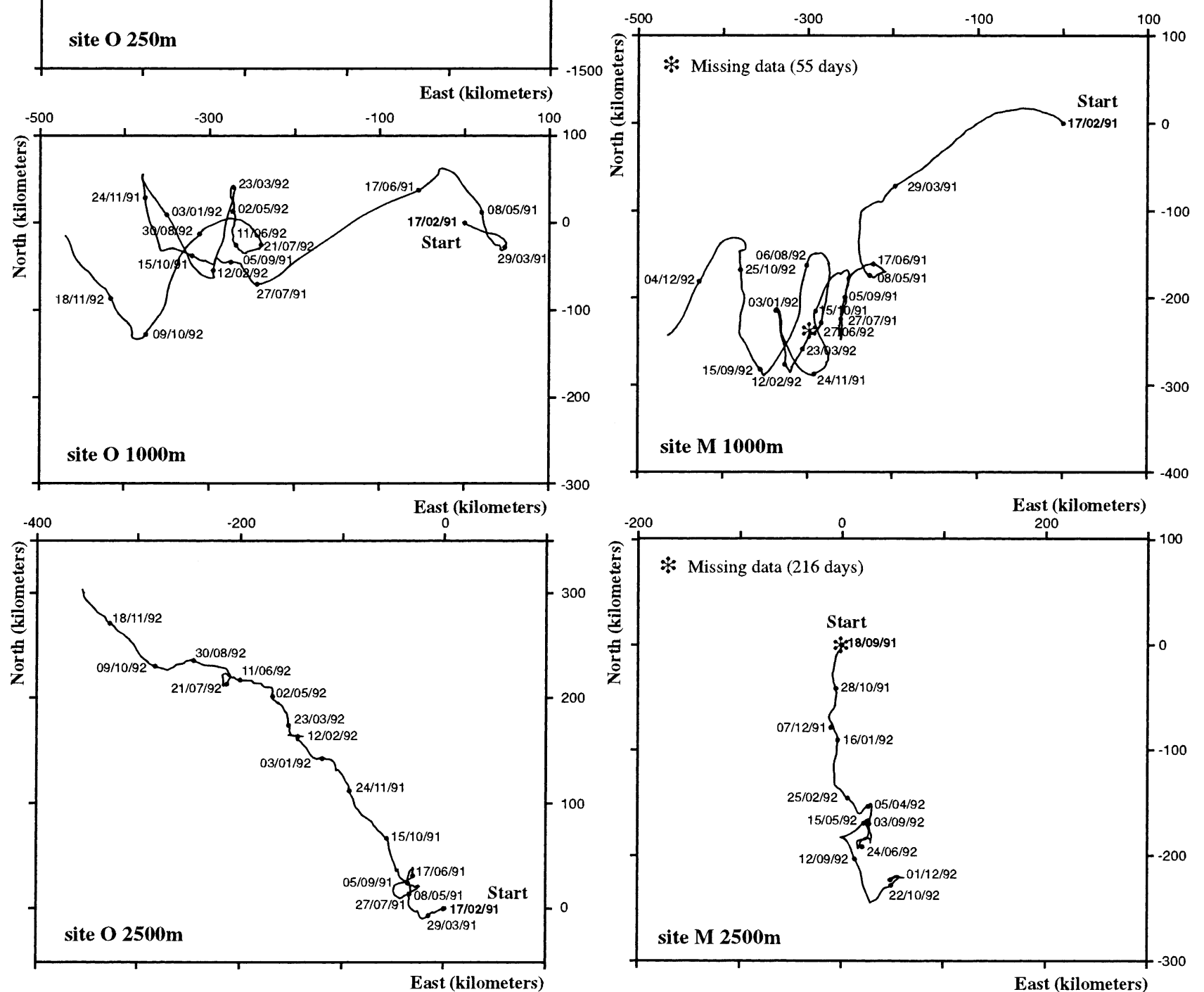

Fig. 7. Progressive vector diagrams of the current recorded at 250, 1000 and $2500 \mathrm{~m}$ at site $\mathrm{O}$ and site $\mathrm{M}$. The scales at 250,1000 and $2500 \mathrm{~m}$ are different. Note that they are fictitious trajectories assuming a homogeneous current field over the whole area (which is not true) and that there are data gaps in some of them.

correlation functions allows one to assume that it was not maximum at time lag 0 . Its second maximum appears for a time lag of $88 \mathrm{~d}$ and the third for $191 \mathrm{~d}, 103 \mathrm{~d}$ later. Assuming this periodicity of $103 \mathrm{~d}(\sim 100 \mathrm{~d}$, as previously observed), one can think that the $\mathrm{V}-\mathrm{V}$ correlation function was maximum for a lag of $-15 \mathrm{~d}(=88-103 \mathrm{~d})$. These lags between 250 and $1000 \mathrm{~m}$ mean that the oscillations are not mainly barotropic at site $\mathrm{O}$, while they seem to be so at site $\mathrm{M}$. 


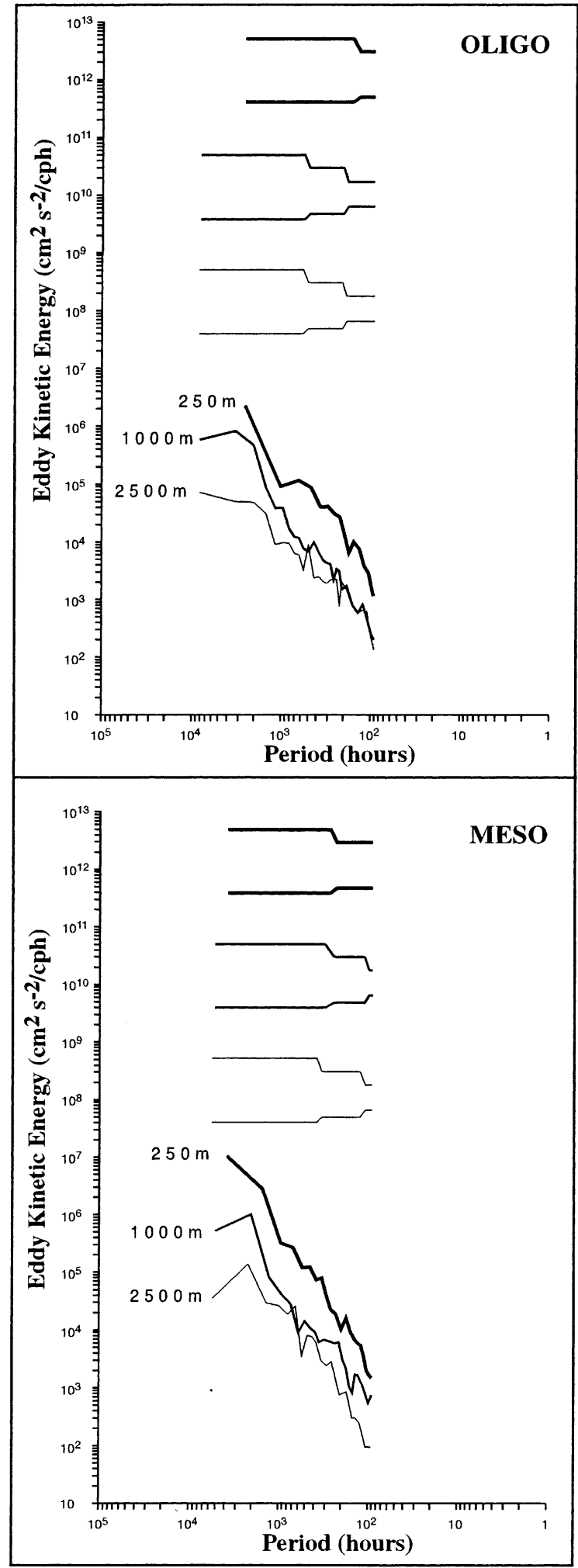

Fig. 8. Total kinetic energy spectrum (with confidence interval at 95\%) of the current meter low-pass filtered data set (cut-off period of $4 \mathrm{~d}$ ) obtained from Eumeli 2 to Eumeli 5. For each level, the calculation was made on the longest available time-series. As a consequence, the frequency resolution of the spectrum is not all the same nor the confidence intervals, depending on the time-series length. Top: site $\mathrm{O}(250,1000$ and $2500 \mathrm{~m})$; bottom: site $\mathrm{M}$ $(250,1000$ and $2500 \mathrm{~m})$.

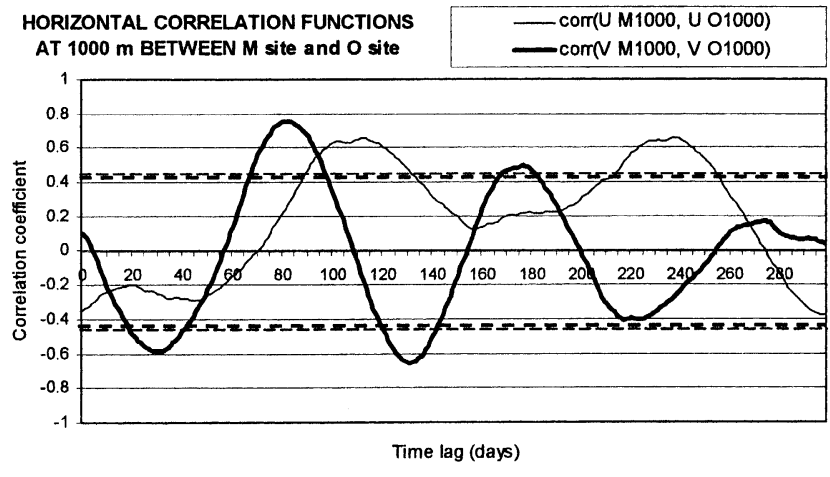

Fig. 9. Horizontal correlation function between low-pass filtered current components at site $\mathrm{M}$ and site $\mathrm{O}$ at $1000 \mathrm{~m}$. The bold (for the $\mathrm{V}$ component) and normal (for the $\mathrm{U}$ component) dashed lines show the values under which the correlation coefficient is not significantly different from zero at the $95 \%$ confidence level (the number of degrees of freedom is deduced from the integral time scales and the time-series lengths).

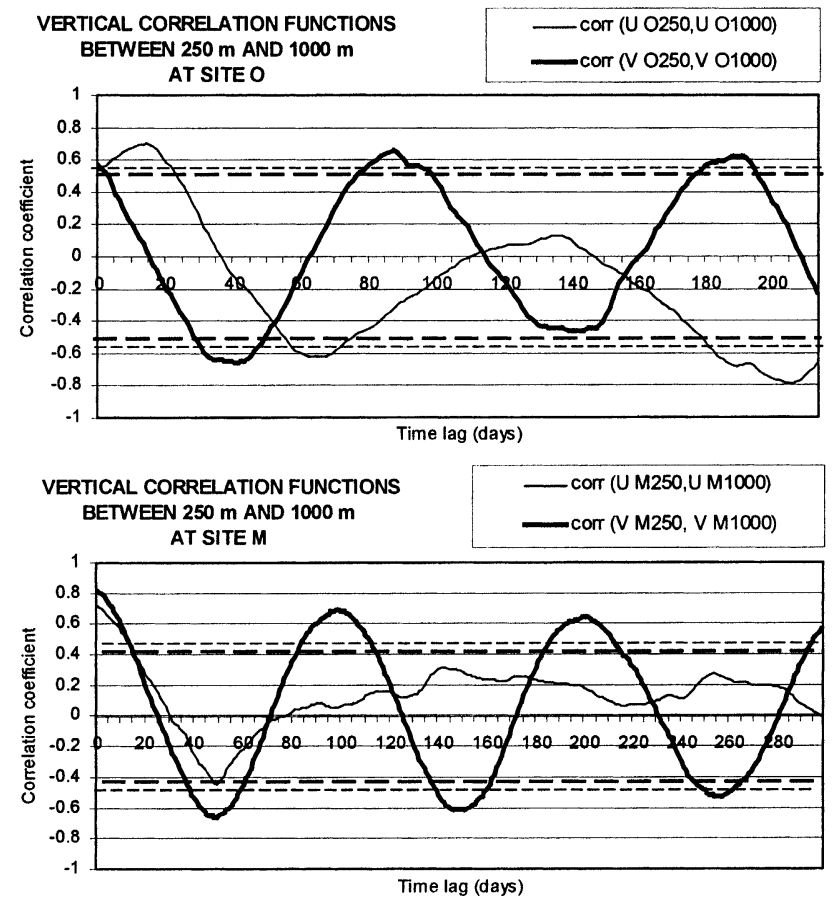

Fig. 10. Vertical correlation function between low-pass filtered current components at 250 and $1000 \mathrm{~m}$ at site $\mathrm{O}$ (top) and site $\mathrm{M}$ (bottom). The bold (for the $\mathrm{V}$ component) and normal (for the $\mathrm{U}$ component) dashed lines show the values under which the correlation coefficient is not significantly different from zero at the $95 \%$ confidence level (the number of degrees of freedom is deduced from the integral time scales and the time-series lengths).

\section{Discussion and conclusion}

Returning to the purpose of these measurements in the framework of the particle flux study in the water column, it is obvious that the dynamics of this region are dominated by high frequency (semi-diurnal, tidal and inertial) oscillations and also by low frequency oscillations at periods of around $100 \mathrm{~d}$. The high current speeds encountered at the upper level have been responsible for several trap failures or bad efficiency that may have had consequences for particle collec- 
tion at this level (Vangriesheim, 1994). Moreover, the low frequency time variability observed in our time-series may be linked to a mesoscale spatial variability having important consequences for the source and transport of the collected particles. These topics are discussed in more detail in Bory et al. (2001). In the present paper, we discuss the origin of the interesting low frequency oscillation observed in the results.

As mentioned above, low frequency time variability as found at 250 and $1000 \mathrm{~m}$ in our data has been previously observed and predicted in the literature (Erasmi et al., 1998; Onken and Klein, 1991; Spall, 1992; Spall et al., 1993). The kinetic energy spectra obtained from our data seem to have a peak between 80 and $125 \mathrm{~d}$, which is in agreement with the frequency of the simulated Rossby waves. The magnitude of the eddy kinetic energy $K_{\mathrm{E}}$ at $1000 \mathrm{~m}$ is 4 and $6 \mathrm{~cm}^{2} \mathrm{~s}^{-2}$ at site $\mathrm{O}$ and site $\mathrm{M}$, respectively, which is higher than that modelled by Spall (1992) $\left(1-2 \mathrm{~cm}^{2} \mathrm{~s}^{-2}\right.$ at $\left.\sim 1000 \mathrm{~m}\right)$. He previously noticed (and explained) such a discrepancy with the IFM data (Müller and Siedler, 1992), which are in agreement with ours. Assuming that the oscillations observed at site $\mathrm{O}$ and site M have their source in the CVFZ, we might calculate the phase speed from the horizontal correlation function Fig. 9. The distance between site $\mathrm{M}$ and site $\mathrm{O}$ is $\sim 1100 \mathrm{~km}$. The observed low frequency oscillations have a period of $\sim 100 \mathrm{~d}$ Fig. 9). From this figure, assuming a westward propagation observed from the vector plots of Fig. 6 (which is consistent with planetary Rossby waves), the lag of $80 \mathrm{~d}$ between site $\mathrm{M}$ and site $\mathrm{O}$ may indicate a wavelength of 1375 or 611 or 393 or $290 \mathrm{~km}$, etc., with increasing wave numbers. This would correspond to a phase speed of 16 or 7 or 4.5 or $3.3 \mathrm{~cm} \mathrm{~s}^{-1}$, etc., respectively. As we do not know the wave number, we may refer to the model of Onken and Klein (1991), who indicate that at $\sim 1000 \mathrm{~m}$, a period of $\sim 100 \mathrm{~d}$ may be found for wavelengths between 500 and $200 \mathrm{~km}$ (their Fig. 7c). From the model of Spall (1992), the westwardpropagating oscillation is a baroclinic Rossby wave with a wavelength of $315 \mathrm{~km}$, a period of $120 \mathrm{~d}$ and thus a phase speed of $3 \mathrm{~cm} \mathrm{~s}^{-1}$. In our data, the closest case is the wavelength of $290 \mathrm{~km}$, with the phase speed of $3.3 \mathrm{~cm} \mathrm{~s}^{-1}$. This shorter period of $100 \mathrm{~d}$ observed in our data instead of the predicted $120 \mathrm{~d}$ period has already been noticed by Spall (1992) by comparing with the W3 mooring (near site M) data of Müller and Siedler (1992) where the period was also $100 \mathrm{~d}$. Another discrepancy with the models is that vertical correlation functions Fig. 10 indicate a baroclinic mode at site $\mathrm{O}$ and a barotropic mode at site $\mathrm{M}$, whereas we should expect a baroclinic mode at site $\mathrm{M}$ to be consistent with the models that attribute the variability in the CVFZ to baroclinic instability.

At this point, we have to note that the period decrease at deeper levels, predicted by models and observed on the IFM data set, also seems to occur on our data. In our Fig. 8, at site $\mathrm{O}$, the low frequency peak found around $2000-3000 \mathrm{~h}$ $(\sim 80-125 \mathrm{~d})$ at $1000 \mathrm{~m}$ is shifted toward $1500-2000 \mathrm{~h}$ $(\sim 60-80 \mathrm{~d})$ at $2500 \mathrm{~m}$ with another peak around $500 \mathrm{~h}$ $(\sim 21 \mathrm{~d})$. At site $\mathrm{M}$, at $2500 \mathrm{~m}$, other peaks also appear at around $600 \mathrm{~h}(25 \mathrm{~d})$ and around $400 \mathrm{~h}$ (16 d). This is consistent with the smaller integral times found in the deep layer, as mentioned above. Such a shift was also observed on the benthic current data set of the Eumeli programme. A peak at periods around $20-30 \mathrm{~d}$ has been found in the near-bottom currents at site O (Khripounoff et al., 1998).

To complete the comparisons with Spall's model prediction, a determination of the $\overline{u^{\prime} v^{\prime}}$ sign would indicate whether the wave radiates from the CVFZ or not. It should be negative in the north of the CVFZ (and positive in the south), which would correspond to northwest-southeast oscillations (southwest-northeast in the south) with a propagation direction to the southwest (to the northwest in the south); thus a positive (negative in the south) northward component of the group velocity (deduced from the planetary-wave dispersion relation, see for example Cushman-Roisin (1994, p. 87)) would be consistent with a radiation away from the CVFZ. In our case, we examined the $u^{\prime} v^{\prime}$ calculated at each site, assuming that site $\mathrm{O}$ is far to the northwest of the CVFZ and that site M may be in the CVFZ or to the south of it. From our whole data set, the $u^{\prime} v^{\prime}$ did not give statistically significant values (not shown). Nevertheless, after summer 1991 (when the oscillations seem well developed), the principal axes orientations of the current velocity variance at $1000 \mathrm{~m}$ are $350^{\circ}$ (energy percentage of $71 \%$ ) at site $\mathrm{O}$ and $010^{\circ}(86 \%$ ) at site $\mathrm{M}$, which is in agreement with the Spall's prediction (see above).

Thus, this data set gave the opportunity to observe the westward propagation of low frequency waves predicted by the models at a location further west than the previous field studies in this area. The low frequency signal found at site $\mathrm{O}$, away from the CVFZ is consistent with Spall's radiation hypothesis. However, our data confirm that the observed periods are smaller than that predicted by the models. This small discrepancy has to be detailed in further studies.

\section{Acknowledgements}

We would like to thank the chief scientists of cruises Eumeli 2 to Eumeli 5 during which the moorings were launched and recovered: Drs M. Sibuet, G. Jacques, A. Morel, P. Buat-Menard and D. Tailliez. The crew, captains and science parties of the N/O Atalante and N/O Suroit cruises and particularly A. Vigot are especially thanked for assisting in all mooring deployment and recovery cruises.

\section{References}

Bory, A., Jeandel, C., Leblond, N., Vangriesheim, A., Khripounoff, A., Beaufort, L., Rabouille, C., Nicolas, E., Tachikawa, K., cheber, H., Buat-Ménard, P., 2001. Downward particle fluxes within different productivity regimes off the Mauritanian upwelling zone (Eumeli program). Deep-Sea Res. I 48, 2251-2282. 
Bournot, C., Vangriesheim, A., Vigot, A., 1995. Campagnes Eumeli 2 à 5. Rapport des données de courant des mouillages de pièges (colonne d'eau). Rapport interne IFREMER DRO/EP 95/202-AV 453 pp.

Cushman-Roisin, B., 1994. Introduction to Geophysical Fluid Dynamics. Prentice Hall, Englewood Cliffs, NJ.

Dadou, I., Garçon, V., Andersen, V., Flierl, G.R., Davis, C.S., 1996. Impact of the North Equatorial Current meandering on a pelagic ecosystem: a modeling approach. J. Mar. Res. 54, 311-342.

Erasmi, W., Siedler, G., Onken, R., 1998. Energy conversion in the Cape Verde Frontal Zone. J. Geophys. Res. 103, 469-479.

Khripounoff, A., Vangriesheim, A., Crassous, P., 1998. Vertical and temporal variations of particle fluxes in the deep tropical Atlantic. Deep-Sea Res. 45, 193-216.

Morel, A., 1996. An ocean flux study in eutrophic, mesotrophic and oligotrophic situations: the Eumeli program. Deep-Sea Res. 43, 1185-1996.

Müller, T.J., Siedler, G., 1992. Multi-year current time series in the eastern North Atlantic Ocean. J. Mar. Res. 50, 63-98.

Onken, R., Klein, B., 1991. A model of baroclinic instability and waves between the ventilated gyre and the shadow zone of the North Atlantic Ocean. J. Phys. Oceanogr. 21, 53-66.
Pierre, C., Vangriesheim, A., Laube-Lenfant, E., 1994. Variability of water masses and of organic production-regeneration systems as related to: eutrophic, mesotrophic and oligotrophic conditions in the Northeast Atlantic ocean. J. Mar. Syst. 5, 159-170.

Siedler, G., Paul, U., 1991. Barotropic and baroclinic tidal currents in the eastern basins of the North Atlantic. J. Geophys. Res. 96, 22259-222271.

Spall, M.A., 1992. Rossby wave radiation in the Cape Verde frontal zone. J. Phys. Oceanogr. 22, 796-807.

Spall, M.A., Richardson, P.L., Price, J., 1993. Advection and eddy mixing in the Mediterranean salt tongue. J. Mar. Res. 51, 797-818.

Tachikawa, K., Jeandel, C., Vangriesheim, A., Dupré, B., 1999. Distribution of rare earth elements and neodynium isotopes in suspended particles of the Tropical Atlantic Ocean (Eumeli site. Deep-Sea Res. 46, 733-756.

Vangriesheim, A., 1994. Validité des prélévements des pièges à particules : exemple de l'opération Eumeli. Le courrier de JGOFS-France 3, 6-7.

Vangriesheim, A., Pierre, C., Laube, E., 1993. Hydrological conditions in the Eumeli areas in the NE Tropical Atlantic: water masses, variability of productivity/regeneration and of particle load. Ann. Inst. océanogr. 69, $15-20$.

Zenk, W., Klein, B., Schroder, M., 1991. Cape Verde frontal zone. Deep-Sea Res. 38, 505-530. 